\title{
RENDICONTI Online della
}

Società Geologica Italiana

Volume 39 Supplemento n. 1 - Aprile 2016

AQUA 2015: Back to the Future!

$42^{\text {nd }}$ International Congress of

International Association of Hydrogeologists

Roma, 13-18 September 2015

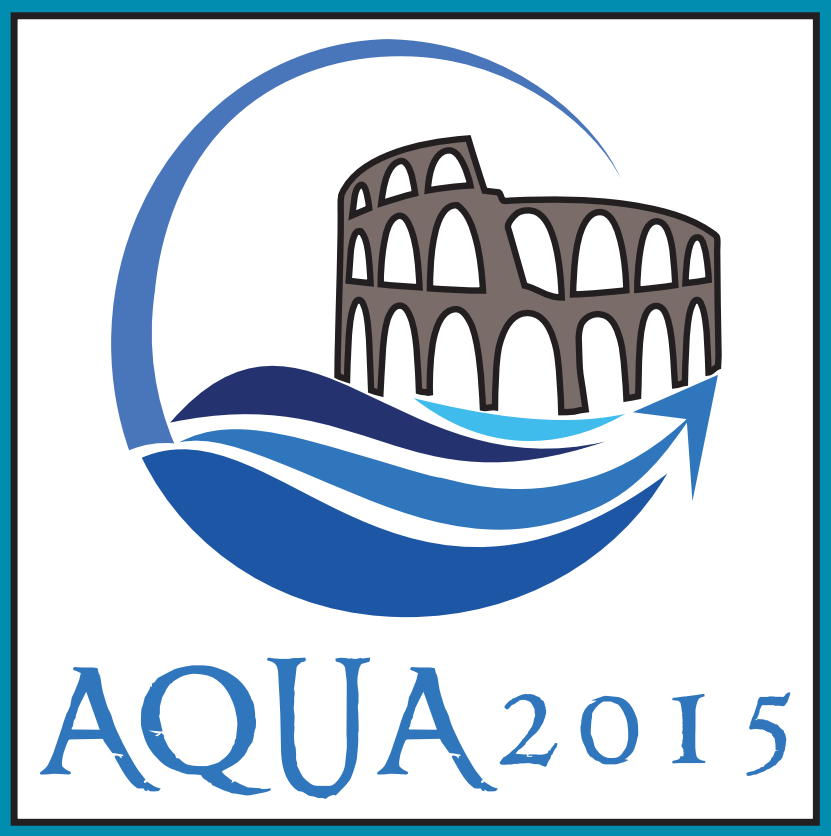

ABSTRACT BOOK

Edited by

Ducci D. \& Petitta M.

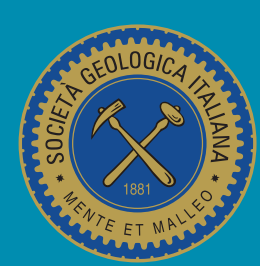

ROMA

SOCIETÀ GEOLOGICA ITALIANA

2016 